\title{
VISUAL 3D PLANOGRAM MEMPERMUDAH PEMASANGAN MATERIAL PROMOSI HANDPHONE
}

Andik Prakasa Hadi ${ }^{1}$, Fandy Achmad Faizal ${ }^{2}$,

Universitas Sains dan Teknologi Komputer, Jl Majapahit 605 Semarang, andik@ stekom.ac.id

Universitas Sains dan Teknologi Komputer, Jl Majapahit 605 Semarang, fandyafaizal@gmail.com

\section{ARTICLE INFO}

Article history:

Received 23 October 2020

Received in revised form 29 October 2020

Accepted 12 November 2020

Available online December 2020

\section{ABSTRACT}

\begin{abstract}
Smartphone retail sales in Indonesia are currently growing very rapidly. Point of Sales Material (POSM) is used to provide information about products to consumers, using displays to stimulate impulsive buying behavior. This study designed a 3D planogram visual media, which can visualize real-time with text, images, and videos. Media that has been developed by researchers is in the very good category with a percentage of $78 \%$ for the promoter segment that is more than 1 year and $77 \%$ for the new promoter segment who has worked at Samsung retail for less than 1 year. From the results of experalidation and user validation, for the aspect of video visualization and the 3D planogram module that has been developed, the category average $\mathrm{AB}$ score is 81-85. The display arrangement process can be done more quickly and precisely because the understanding of the planogram increases.
\end{abstract}

Keywords: POSM, planogram, visual 3D

\section{PENDAHULUAN}

Semakin pesatnya pertumbuhan smartphone saat ini, membuat setiap brand smartphone berlomba-lomba untuk menguasai market yang ada di seluruh dunia. Menurut data dari Canalys research yang merupakan salah satu lembaga riset terpercaya di dunia di bidang teknologi, selama Q3 yakni dari bulan Juli - September 2019 jumlah smartphone yang dikirimkan di berbagai negara mencapai 352 juta unit. Angka tersebut menunjukan adanya kenaikan yang cukup baik pada quartal ketiga ini. Samsung masih merajai untuk distribusi smartphone untuk saat ini. Selain itu ada beberapa brand seperti huawei, apple, xiaomi, oppo, dan brand lainnya juga sangat pesat perkembangannya melakukan distribusi dan penjualan untuk smartphone saat ini.

Saat bisa dilihat betapa banyak toko handphone yang ada di berbagai kota bahkan menjamur di pinggiran kota bermunculan toko-toko handphone baru yang sudah dibuka. Melihat hal tersebut bisnis penjualan handphone sungguh sangat berpotensi besar. Samsung merupakan merek produsen handphone yang cukup lama berkiprah di Indonesia [1]. Merek ini menjadi pemimpin market dan masih mempunyai daya Tarik tersendiri bagi konsumen. Hampir di setiap toko terlihat brand Samsung, hal tersebut dikarenakan daya Tarik brand ini masih menjadi senjata utama untuk menarik market handphone yang ada. Namun persaingan di dunia smartphone ini tidak hanya masalah Spesifikasi produk yang diberikan setiap produsen 
handphone saja. Namun faktor pembelian handphone di toko tertentu juga dipengaruhi banyak faktor, diantaranya penataan display yang menarik untuk membuat konsumen lebih nyaman dan percaya dengan toko tersebut. Karena faktor display produk juga mempengaruhi keputusan pembelian Smartphone di suatu toko [2].

Dany Setiawan [3] dalam penelitiannya menyatakan Store planning dan merchandising secara parsial berpengaruh signifikan terhadap impulse buying behaviour pengunjung. Menurut Melisa [4] Point-of-purchase dapat meningkatkan impulse buying hal ini dapat dilihat dari pembagian dari lingkungan belanja toko menjadi 2 efek terpisah dalam point-of-purchase (POP) toko, yaitu perilaku dorongan membeli dan suasana supermarket.

Berdasarkan study lapangan dan survei yang dilakukan, faktor penataan sebuah toko dan display cukup mempengaruhi saat konsumen akan melakukan pembelian. Konsumen akan lebih nyaman saat display dan penataan toko rapi dan tertata. Bersumber dari hal tersebut ternyata setiap brand berlomba untuk menguasai display di masing masing toko yang kerjasama dengan mereka di berbagai kota. Hal tersebut bertujuan agar konsumen atau orang yang memasuki toko tersebut akan melihat semua material promo dan brand image tersebut. Ternyata masing masing brand mempunyai sebuah planogram atau acuan khusus untuk mendisplay produknya. Planogram merupakan suatu konsep gambar 2D yang sangat sederhana yang di dalamnya merupakan rencana pemajangan produk berdasarkan alur kebiasaan belanja konsumen [5].

Penelitian ini mengambil sampel brand Samsung. Pemasaran produk ini mempunyai acuan khusus pentaan display produk meliputi Penataan RDU ( Retail Demo Unit ) yang harus terpasang pada lokasi meja display. Selain itu juga penataan mengenai stock yang wajib terpajang dan urutan penataannya. Serta accessories penunjang smartphone juga tidak luput dari planogram penataan. Dengan demikian faktor display sebuah produk dan material promosi sangat berpengaruh terhadap pembelian konsumen selain faktor lainnya. Dari data RIS ( Retail Index Standart ) [6]. yang dimiliki pihak Samsung untuk acuan pemasangan segala macam material promosi yg ada. Terdapat berbagai planogram atau diagram tata letak sesuai dengan masing-masing kategori brandshop yang bekerja sama dengan Samsung. Samsung memliliki acuan untuk penataan display dan material promosi yang wajib terpasang di masing - masing toko partner yang bekerja sama dengannya. Dari data yang peneliti dapatkan untuk planogram atau diagram pemasangannya hanya berupa gambar $2 \mathrm{D}$ dan penjelasan yang kurang detail mengenai pemasangan untuk masing - masing media promosi yang ada. Sehingga untuk memahami gambar yang hanya berupa planogram saja menjadi sebuah masalah di dalam melakukan display produk.

Orang yang bertugas menjelaskan dan menyampaikan informasi seputar kelebihan ponsel kepada calon pembeli ini disebut dengan promotor. Selain bertugas untuk mendorong penjualan sebuah brand smartphone, saat ini juga mempunyai tugas untuk melakukan display produk dan penataan di toko yang mereka tempati. Dengan tujuan untuk menarik konsumen atau sebagai media yg digunakan untuk menjelaskan produk" [7]. Pada store retail Samsung saat ini yang berkewajiban untuk melakukan penataan display adalah promotor. Selain bertugas untuk menjualkan produk dari brand tersebut, mereka di tuntut untuk bisa melakukan display material promosi secara rapi dan benar. Sehingga display tersebut bisa untuk menambah minat konsumen untuk membeli suatu produk yang mereka jual. Namun yang terjadi di lapangan setelah peneliti melakukan survey dan pengamatan di beberapa store retail Samsung, Penempatan dan cara display yang dilakukan oleh promotor sangat jauh berbeda dengan apa yang ada di RIS ( Retail Index Standart ). Dan hasil wawancara yang dilakukan diantaranya menyebutkan kesusahan untuk memahami sebuah gambar planogram yang telah diberikan. Karena info yang di dapatkan sangat minim informasi sehingga promotor meletakan media promosi kurang begitu tepat. Sehingga menyebabkan kurang fungsionalnya media promosi yg sudah dicetak atau di buat oleh perusahaan.

Dengan adanya masalah tersebut maka peneliti mengembangkan rancangan design berupa visual 3D [8] yang berasal dari penerjemahan planogram yang digunakan Samsung. Rancangan tersebut diharapkan lebih mudah dipahami oleh promotor yang bertugas untuk menata display di masing - masing retail Samsung. Serta diharapkan penataan dan display akan sesuai dengan acuan planogram yang sudah dibuat oleh Samsung itu sendiri.

JURNAL ILMIAH KOMPUTER GRAFIS Vol. 13, No. 2, December 2020 : 42-55


Dalam studi pendahuluan peneliti melakukan survey melalui kuesioner. Penulis melibatkan 20 responden yang terdiri dari pihak promotor di area Salatiga 17 orang dan 3 orang dari promotor Ambarawa. Studi pendahuluan menunjukkan hasil sebagai berikut :

- $65 \%$ responden berpendapat setuju bahwa Planogram dari perusahaan yang sekarang susah untuk dipahami dari pihak promotor. $10 \%$ sangat setuju dan $25 \%$ mengatakan tidak setuju bahwa desain planogram susah untuk dipahami.

- $60 \%$ responden berpendapat tidak setuju bahwa mereka paham mengenai nama material promo yang ada di toko. $10 \%$ sangat tidak setuju, 30\% berpendapat setuju bahwa mereka paham tentang nama material promo.

- $\quad 70 \%$ responden berpendapat setuju bahwa desain planogram harus ada perbaikan dari yang sekarang. $10 \%$ berpendapat sangat setuju, $20 \%$ mengatakan tidak setuju.

Dari uraian hasil kuesionar diatas, peneliti dapat menyimpulkan bahwa sebagian besar promotor berpendapat bahwa desain planogram yang sekarang masih susah dipahami dan harus ada perubahan desain yang lebih menarik dan mudah untuk dipahami. Oleh karena itu penelitian mengembangkan perancangan desain Visual 3D dalam bentuk buku manual dan Video 3D yang dapat memudahkan promotor untuk memahami masing-masing nama material promo dan cara pemasangannya. Diharapkan juga akan lebih mempercepat proses pemasangan dan tersampaikannya promosi ke konsumen untuk menambah penjualan di area Salatiga.

Adapun tujuan yang ingin dicapai oleh penulis dalam penelitian ini adalah untuk merancang sebuah visual 3D yang mudah dipahami dan di aplikasikan. Pada akhirnya dengan penelitian penerjemahan dari bentuk planogram ke dalam visual 3D dapat memberi manfaat bagi divisi promotor, pengusaha retail, dan perancang planogram untuk menjawab beberapa kebutuhan berikut:

- Membuat dokumen yang berisikan panduan dan nama material promo planogram untuk mempermudah pemasangan POSM kepada promotor.

- Membuat Media Informasi 3D Visual Object dalam bentuk video yang menarik dan mudah dipahami. Sehingga dapat tersampaikan pesan dari masing - masing promosi yang ada dan sesuai dengan RIS dari perusahaan.

\section{METODA PENELITIAN}

Peneliti menyusun kerangka berfikir (gambar 1.) penelitian yang menggambarkan tahapan alur pikir penelitian dalam menyusun reka pemecahan masalah sebagai berikut :

a. Pada tahap awal kerangka berpikir penulis menemukan sebuah masalah yang sedang terjadi pada model lama planogram di Retail Samsung.

b. Tahap kedua peneliti melakukan analisa permasalahan dengan menggunakan berbagai sumber data mengenai planogram yang sudah ada dan observasi dilapangan, sehingga menghasilkan sebuah data yang valid.

c. Tahap ketiga peneliti mulai melakukan pengembangan dengan berbagai variable yang ada dilapangan seperti contoh : Hardwaredan software pembuat 3D Visual, SDM untuk pembuat visual 3D, Kebijakan perusahaan yang berlaku, pemahaman promotor sebagai object utama yang melakukan penataan material promosi, Smartphone sebagai media yang digunakan untuk membuka file.

d. Prinsip dan konsep model baru merupakan tahap selanjutnya setelah peneliti melakukan di tahap pengembangan. Pada tahap ini peneliti membuat sebuah media pembelajaran multimedia mengenai Visual 3D object planogram dan menyiapkan berbagai macam alternative desain yang bias menjadi pilihan. Setelah itu aka ada tahap pengujian desain yang hasilnya akan diketahui apakah rancangan desain ini berhasil atau gagal. Jika hasilnya berhasil desain akan bias digunakan ke pengguna end user dan apabila gagal akan masuk ke tahap revisi desain berdasarkan prinsip dan konsep yang sudah ada. 


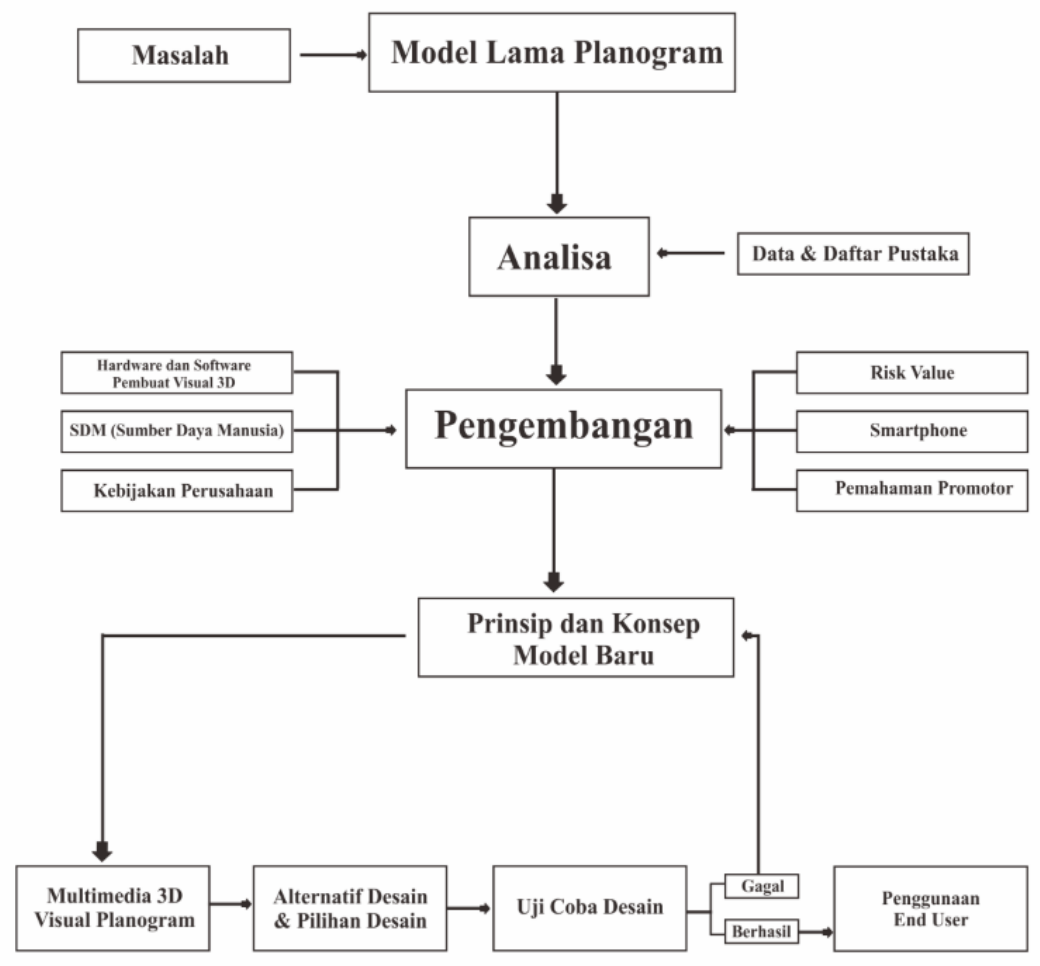

Gambar 1. Bagan Kerangka Penelitian

Pengambilan data dilakukan sebanyak dua kali.Pengambilan data pertama bertujuan untuk menentukan desain seperti apa yang diinginkan oleh promotor sebagai acuan pemasangan material promosi di toko. Lalu pengambilandata kedua diambil untuk melihat respon promotor terhadap desain yang sudah dikembangkan. Data kedua diambil dengan cara membagikan kuisioner yang berisi pertanyaan seputar hasil redesain yang telah dibuat. Kuisioner sejumlah 30 kuisioner digital dibuat dengan Google Form dan dibagikan kepada promotor yang ada di area salatiga dan ambarawa.

Langkah Pengembangan desain meliputi 6 tahapan :

a. Peneliti melakukan studi literatur yang berkaitan dengan permasalahan yang dikaji yaitu tentang planogram, pemahaman promotor mengenai planogram dari perusahaan yang sudah ada saat ini dan pengukuran kebutuhan promotor dalam acuan pemasangan material promosi, penelitian ini dilakukan dalam skala kecil, dan persiapan untuk merumuskan kerangka kerja penelitian.

b. Peneliti menyusun rencana penelitian yang meliputi merumuskan kecakapan dan keahlian yang berkaitan dengan permasalahan, menentukan tujuan yang akan dicapai pada setiap tahapan, desain atau langkah-langkah penelitian dan jika mungkin/diperlukan melaksanakan studi kelayakan secara terbatas.

c. Peneliti mengembangkan bentuk awal dari produk yang akan dihasilkan. Termasuk dalam langkah ini adalah persiapan komponen pendukung, menyiapkan pedoman dan buku petunjuk, dan melakukan evaluasi terhadap kelayakan alat-alat pendukung.

d. Peneliti melakukan ujicoba lapangan awal dalam skala terbatas, dengan melibatkan 1 sampai dengan 3 Retail Samsung yang ada di area, dengan jumlah 6-12 subyek. Pada langkah ini pengumpulan dan analisis data dapat dilakukan dengan cara wawancara, observasi atau angket.

e. Peneliti melakukan perbaikan terhadap produk awal yang dihasilkan berdasarkan hasil ujicoba awal. Perbaikan ini sangat mungkin dilakukan lebih dari satu kali, sesuai dengan hasil yang ditunjukkan dalam ujicoba terbatas, sehingga diperoleh draft produk (model) utama yang siap diuji coba lebih luas. 
f. Peneliti melakukan ujicoba utama yang melibatkan khalayak lebih luas, yaitu 5 sampai 15 Retail Samsung, dengan jumlah subyek yang lebih banyak lagi. Pengumpulan data dilakukan secara kuantitatif, terutama dilakukan terhadap kinerja sebelum dan sesudah penerapan ujicoba. Hasil yang diperoleh dari ujicoba ini dalam bentuk evaluasi terhadap pencapaian hasil ujicoba (desain model) yang dibandingkan dengan kelompok kontrol. Dengan demikian pada umumnya langkah ini menggunakan rancangan penelitian eksperimen

Validasi ahli (expert judgement) dilakukan dengan responden para ahli atau pakar dalam bidang yang terkait dengan produk yang dikembangkan atau dibuat, dengan kriteria penilaian sebagaimana tabel 1. Validasi ahli dilakukan untuk me-review produk yang telah dibuat, sehingga diperoleh masukan untuk perbaikan produk.

Tabel 1 Kriteria Penilaian Ahli (sumber peneliti)

\begin{tabular}{|l|l|}
\hline \multicolumn{1}{|c|}{ KRITERIA PENILAIAN } & \multicolumn{1}{c|}{ INDIKATOR } \\
\hline Desain Visual 3D Planogram & $\begin{array}{l}\text { Desain yang menarik } \\
\text { Desain mudah dipahami } \\
\text { Desain sesuai dengan planogram }\end{array}$ \\
\hline Kemudahan Penggunaan & $\begin{array}{l}\text { Mampu di putar di smartphone } \\
\text { Dapat di putar dalam media player maupun } \\
\text { komputer }\end{array}$ \\
\hline Kualitas Informasi & $\begin{array}{l}\text { Informasi yang lengkap dan jelas } \\
\text { Gambar dan teks dapat dibaca dan dilihat } \\
\text { dengan jelas }\end{array}$ \\
\hline
\end{tabular}

Teknik analisis data yang digunakan untuk menganalisis data hasil penilaian kelayakan adalah dengan teknik analisis deskriptif. Adapun teknik deskriptif presentase yang akan digunakan, dapat dituliskan sebagai berikut:

Persentase $=\frac{\Sigma(\text { jawaban } \times \text { bobot tiap pilihan })}{\mathrm{n} \times \text { bobot tertinggi }} \times 100 \%$

Keterangan :

$\Sigma:$ Jumlah

$\mathrm{n}$ : Jumlah seluruh item angket

\section{HASIL DAN PEMBAHASAN}

\subsection{Penelitian Pendahuluan}

Dalam tahap ini dilakukan identifikasi perkiraan kebutuhan mempelajari literature dan meneliti dalam skala kecil. Penelitian awal ini dilakukan di toko retail Samsung area ambarawa dan salatiga yang melibatkan 30 promotor. Responden adalah karyawan yang masih aktif bekerja di samsung. Penelitian awal dilakukan untuk mendapatkan informasi kebutuhan dalam penelitian.

Hasil data kuisioner terhadap 30 responden yang dibagi menjadi dua kelompok pertanyaan

- Kelompok pertanyaan ketertarikan media visual 3D sebagai acuan pemasangan material promo.

- Kelompok pertanyaan kemudahan pemahaman planogram ke dalam visual 3D

Dari kuisioner dapat di tarik rating scale dengan rumus penghitungan sebagai berikut : 
$\mathrm{P}=\frac{\text { Skor hasil pengumpulan data }}{\text { skor ideal }} \times 100 \%$

Keterangan :

$\mathrm{P} \quad=$ angka persentase

Skor ideal = skor tertinggi tiap butir $\mathrm{x}$ jumlah responden $\mathrm{x}$ jumlah butir

Dengan menggunakan skala, Gonia menggolongkan empat kategori validasi, yaitu :

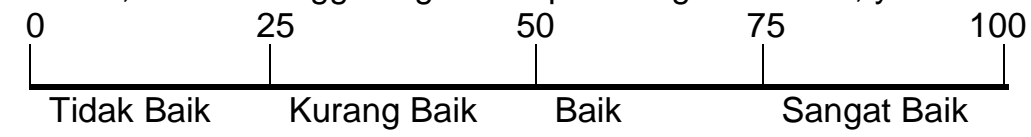

Kategori tersebut bila diinterpretasikan bisa dilihat dalam sebuah tabel 2 seperti berikut : Tabel 2 Presentasi Nilai Instrumen Penelitian

\begin{tabular}{|l|l|}
\hline Skor Presentase(\%) & Interpretasi \\
\hline $0<25$ & Tidak Baik \\
\hline $25<50$ & Kurang Baik \\
\hline $50<75$ & Baik \\
\hline $75-100$ & Sangat Baik \\
\hline
\end{tabular}

Analisa data perkelompok pertanyaan :

a. Kelompok 1 ( Promotor lama / lebih dari 1 tahun ) :

Pertanyaan (yang di berikan berkaitan tentang ketertarikan responden terhadap media promosi melalui video. Hasil datanya dapat dilihat dalam tabel 3 berikut :.

Tabel 3 Hasil Kuisioner Kelompok1 (sumber peneliti)

\begin{tabular}{|c|c|c|c|c|c|c|}
\hline Keterangan & Pertanyaan & $\begin{array}{l}\text { SS } \\
(4)^{\prime}\end{array}$ & S (3) & $\begin{array}{l}\mathrm{KS} \\
(2)\end{array}$ & TS (1) & Jumlah skor \\
\hline \multirow{11}{*}{ Pertanyaan } & Butir 1 & 12 & 6 & 3 & 1 & 73 \\
\hline & Butir 2 & 15 & 5 & 1 & 1 & 78 \\
\hline & Butir 3 & 7 & 14 & - & 1 & 71 \\
\hline & Butir 4 & 10 & 9 & 3 & - & 73 \\
\hline & Butir 5 & 10 & 11 & 1 & - & 75 \\
\hline & Butir 6 & 5 & 14 & 2 & 1 & 67 \\
\hline & Butir 7 & 3 & 17 & 1 & 1 & 66 \\
\hline & Butir 8 & 3 & 15 & 2 & 2 & 63 \\
\hline & Butir 9 & 3 & 6 & 11 & 2 & 54 \\
\hline & Butir 10 & 5 & 15 & 2 & - & 69 \\
\hline & & & & & & 689 \\
\hline Skor ideal & \multirow{2}{*}{\multicolumn{5}{|c|}{$4 \times 10 \times 22$}} & 880 \\
\hline & & & & & & 0,782 \\
\hline
\end{tabular}

No butir untuk hasil pertanyaan kuesioner planogram visual $3 D$ sebagai acuan pemasangan material promo ada 10 butir yaitu :

1) Pertanyaan ketertarikan melihat planogram visual $3 D$ yang baru dari 22 responden untuk katagori sangat setuju mencapai $54 \%$, setuju $28 \%$, kurang setuju $13 \%$, dan tidak setuju $5 \%$.

2) Pertanyaan planogram visual 3D mudah diakses dari 22 responden untuk katagori sangat setuju $68 \%$, setuju $22 \%$, kurang setuju $5 \%$, tidak setuju $5 \%$.

3) Pertanyaanplanogram visual 3D planogram memudahkan mendapatkan informasi dari 22 responden yang dengan katagori sangat setuju sebanyak $32 \%$, setuju $63 \%$, tidak setuju $5 \%$.

4) Pertanyaan visual 3D dapat menjadi acuan pemasangan material promo dari 22 responden untuk katagori sangat setuju $45 \%$, setuju $41 \%$, kurang setuju $14 \%$, tidak setuju $0 \%$.

5) Pertanyaan Planogram berbentuk visual 3D sesuai dengan keadaan POSM di Tokodiambil dari 22 responden yang menyatakan sangat setuju 45\%, setuju 50\%, kurang setuju 5\%. 
6) Dengan pertanyaan planogram visual 3Dyang baru dibanding yang lama lebih mudah dipahami promotor dari 22 responden yang menjawab sangat setuju $22 \%$, setuju $63 \%$, kurang setuju $10 \%$, tidak setuju $5 \%$.

7) Pertanyaan planogram visual $3 D$ lebih mempercepat pemasangan material promosi di toko dari 22 responden yang menjawab sangat setuju $20 \%$, setuju $73 \%$, kurang setuju 3,3\%, tidak setuju 3,3\%.

8) Butir soal pertanyaan informasi yang disampaikan melalui planogram visual $3 D$ sangat mudah diingat dari 22 responden yang menjawab sangat setuju 13\%, setuju $77 \%$, kurang setuju5\%, tidak setuju $5 \%$.

9) Butir soal pertanyaan acuan pemasangan promosi hanya dengan media visual 3D saja tanpa modul dari 22 responden yang menajwab sangat setuju 13\%, setuju $27 \%$, kurang setuju $50 \%$, tidak setuju $10 \%$.

10) Butir soal pertanyaan visual 3D planogram dapat memudahkan promotor mengetahui tentang nama material promosi yang ada dari 22 responden yang menjawab sangat setuju $22 \%$, setuju $68 \%$, kurang setuju $10 \%$, tidak setuju $0 \%$.

Jumlah total nilai untuk butir tersebut $73+78+71+73+75+67+66+63+54+69=689$.

Skor idealnya $=4 \times 10 \times 22=880$. Jadi ketertarikan media planogram visual 3D sebagai promosi $=496: 600=0,782$ atau $78 \%$ dari yang diharapkan.

b. Kelompok 2 ( Promotor baru / kurang dari 1 tahun ) :

Pertanyaan yang di berikan berkaitan tentang kemudahan pemahaman planogram ke dalam visual 3D. Berikut ini adalah tabel 4 hasil planogram ke dalam visual 3D .

Tabel 4 Hasil Kusioner Kelompok 2 (sumber peneliti)

\begin{tabular}{|c|c|c|c|c|c|c|}
\hline Keterangan & Pertanyaan & SS (4) & $S(3)$ & KS (2) & TS (1) & Jumlah skor \\
\hline \multirow[t]{10}{*}{ Pertanyaan } & Butir 1 & 1 & 7 & - & - & 25 \\
\hline & Butir 2 & 3 & 4 & 1 & - & 26 \\
\hline & Butir 3 & 1 & 6 & 1 & - & 24 \\
\hline & Butir 4 & 2 & 6 & - & - & 26 \\
\hline & Butir 5 & 3 & 4 & - & 1 & 25 \\
\hline & Butir 6 & 1 & 6 & 1 & - & 24 \\
\hline & Butir 7 & 3 & 5 & - & - & 27 \\
\hline & Butir 8 & 3 & 4 & 1 & - & 26 \\
\hline & Butir 9 & - & 4 & 3 & 1 & 19 \\
\hline & Butir 10 & 3 & 4 & 1 & - & 26 \\
\hline & & & & & & 248 \\
\hline Skor ideal & \multicolumn{5}{|c|}{$4 \times 10 \times 8$} & 320 \\
\hline & & & & & & 0,775 \\
\hline
\end{tabular}

No butir untuk hasil pertanyaan kuesioner planogram visual $3 D$ sebagai acuan pemasangan material promo ada 10 butir yaitu :

1) Pertanyaan ketertarikan melihat planogram visual $3 D$ yang baru dari 8 responden untuk katagori sangat setuju mencapai $12 \%$, setuju $88 \%$, kurang setuju $0 \%$, dan tidak setuju $0 \%$.

2) Pertanyaan planogram visual $3 D$ mudah diakses dari 8 responden untuk katagori sangat setuju $37 \%$, setuju $50 \%$, kurang setuju $13 \%$, tidak setuju $0 \%$.

3) Pertanyaanplanogram visual 3D planogram memudahkan mendapatkan informasi dari 8 responden yang dengan katagori sangat setuju sebanyak $12,5 \%$, setuju $75 \%$, kurang setuju $12,5 \%$.

4) Pertanyaan visual 3D dapat menjadi acuan pemasangan material promo dari 8 responden untuk katagori sangat setuju $25 \%$, setuju $75 \%$, kurang setuju $0 \%$, tidak setuju $0 \%$. 
5) Pertanyaan Planogram berbentuk visual 3D sesuai dengan keadaan POSM di Tokodiambil dari 8 responden yang menyatakan sangat setuju $37 \%$, setuju $50 \%$, tidak setuju $13 \%$.

6) Dengan pertanyaan planogram visual 3Dyang baru dibanding yang lama lebih mudah dipahami promotor dari 8 responden yang menjawab sangat setuju 12,5\%, setuju $75 \%$, kurang setuju $12,5 \%$, tidak setuju $0 \%$.

7) Pertanyaan planogram visual $3 D$ lebih mempercepat pemasangan material promosi di toko dari 8 responden yang menjawab sangat setuju 37\%, setuju $63 \%$, kurang setuju 0\%, tidak setuju $0 \%$.

8) Butir soal pertanyaan informasi yang disampaikan melalui planogram visual $3 D$ sangat mudah diingat dari 8 responden yang menjawab sangat setuju $37 \%$, setuju $50 \%$, kurang setuju $12 \%$, tidak setuju $0 \%$.

9) Butir soal pertanyaan acuan pemasangan promosi hanya dengan media visual 3D saja tanpa modul dari 8 responden yang menajwab sangat setuju 0\%, setuju 50\%, kurang setuju 37\%, tidak setuju $13 \%$.

10) Butir soal pertanyaan visual 3D planogram dapat memudahkan promotor mengetahui tentang nama material promosi yang ada dari 8 responden yang menjawab sangat setuju 37\%, setuju $50 \%$, kurang setuju $13 \%$, tidak setuju $0 \%$.

Jumlah total nilai untuk butir tersebut $25+26+24+26+25+24+27+26+19+26=248$. Skor idealnya $=4 \times 10 \times 8=320$. Jadi ketertarikan media planogram visual 3D sebagai promosi $=248: 320=0,775$ atau $77 \%$ dari yang diharapkan.

Dalam pembuatan visual 3D planogram pada retail Samsung penulis mengutamaan kejelasan informasi yang terkandung dalam video dan modul, kemenarikan gambar dan intruksi teks. Sehingga dalam penyajianya promotor yang bertugas memasang material promosi ini akan lebih paham dan tertarik untuk melihat video dan modul yang berupa file pdf tersebut sampai akhir. Flowcart objek pengembangan ini dibuat agar dalam alur pembuatan visual $3 d$ planogram ini lebih mudah sehingga dapat tepat sasaran.

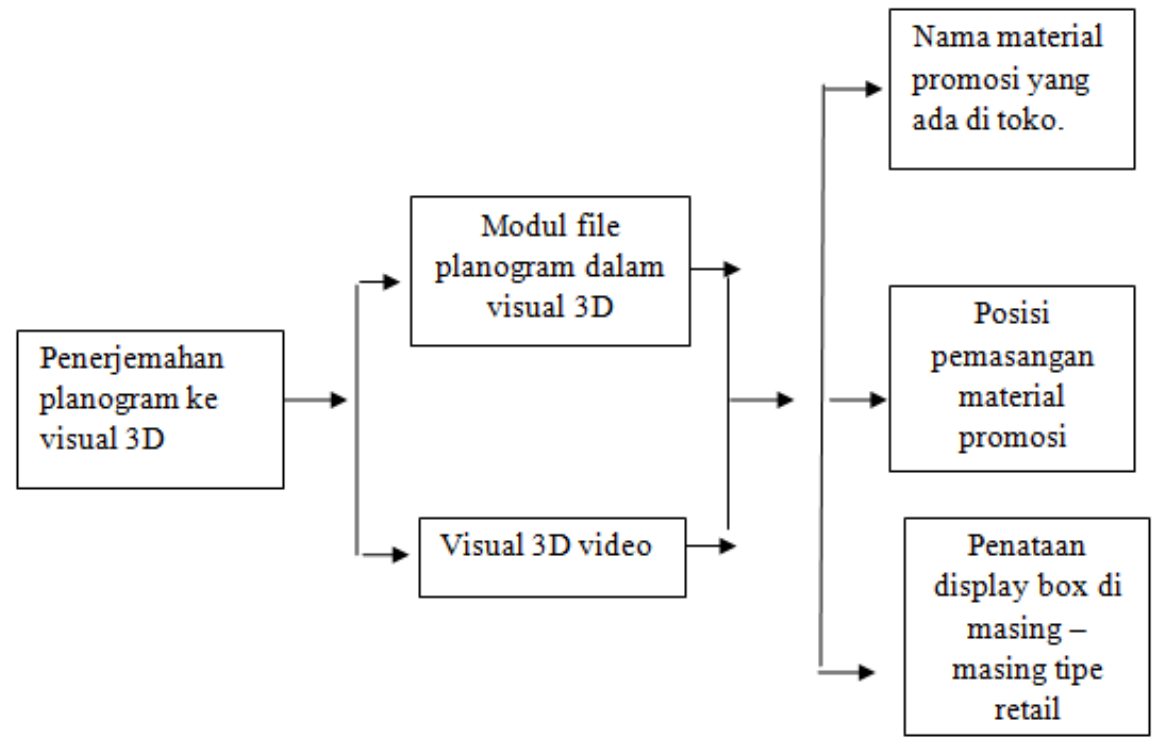

Gambar 2. Flowchart Isi visual 3D planogram)

Jenis dan nama POSM yang ada di toko retail Samsung yang ada di area salatiga terlihat dalam tabel 5. POSM sendiri mempunyai Singkatan Point of Sales Material merupakan sebuah material promosi penjualan sebuah produk, POSM juga sering diistilahkan dengan POP. Point-of Purchase Display (POP) [9] merupakan display produk dengan menggunakan berbagai macam point of purchase seperti poster untuk memberikan informasi mengenai produk kepadakonsumen. Peritel mengunakan display untuk menstimulasi perilaku pembelian impulsif. Melalui display dan point-of purchase, peritel dan manufaktur dapat menjelaskan informasi tentang produknya konsumen [10].

JURNAL ILMIAH KOMPUTER GRAFIS Vol. 13, No. 2, December $2020: 42-55$


Tabel 5. Nama POSM yang terpasang di toko retail

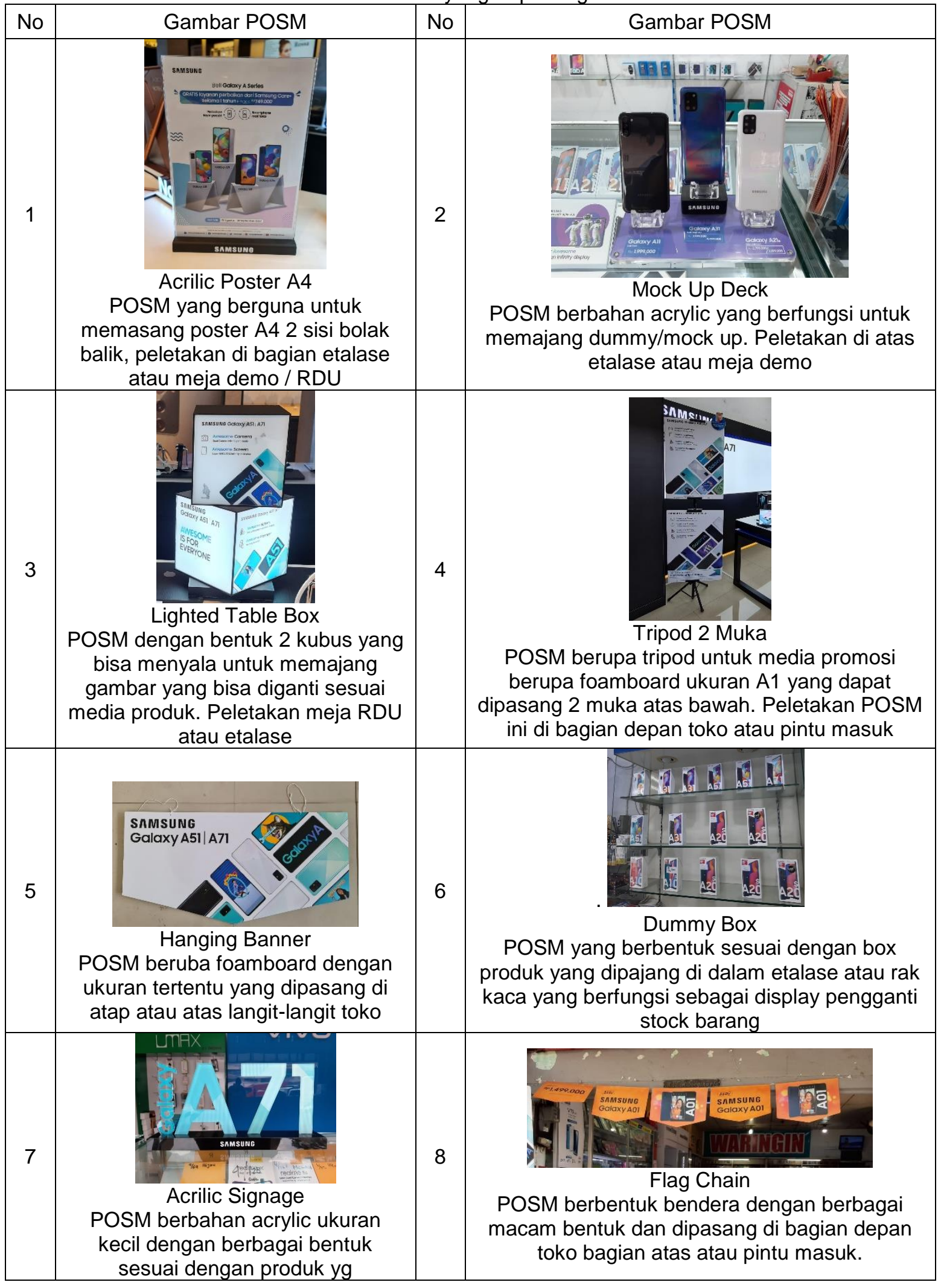

VISUAL 3D PLANOGRAM MEMPERMUDAH PEMASANGAN MATERIAL PROMOSI HANDPHONE (Andik Prakasa Hadi) 
dilaunching. Pemasangan di atas etalase atau meja RDU

\subsection{Pengembangan produk}

Tahapan pembuatan visual 3D planogram sesuai dengan konsep yang telah direncanakan adalah :.

- Proses diawali dengan pemindahan file kedalam laptop, dijadikan satu folder bersama poster yang telah dibuat di Corel Draw X7, agar mudah dalam pembuatan di SketchUp [7].

- Setelah pembuatan masing masing material promosi yang ada di retail Samsung maka tahap selanjutnya adalah penataan sesuai dengan planogram awal yang sudah ada di perusahaan.

- Dan langkah selanjutnya adalah dengan render 1 bagian material promosi sehingga menjadi format .jpg atau .png sehingga dapat dijadikan bahan untuk membuat modul.

- Selain render dalam format gambar pada saat di sketchup juga take animation masing masing POSM sehingga bisa dijadikan bahan untuk pembuatan video di camtasia 9.

- Dan proses terakhir adalah menggabungkan semua animation file ke dalam video dan di render dalam bentuk format .mp4 sehingga bisa di akses untuk semua promotor yang bertugas melakukan pemasangan POSM di toko.

\subsubsection{Acuan planogram pemasangan display yang ada di etalase toko.}

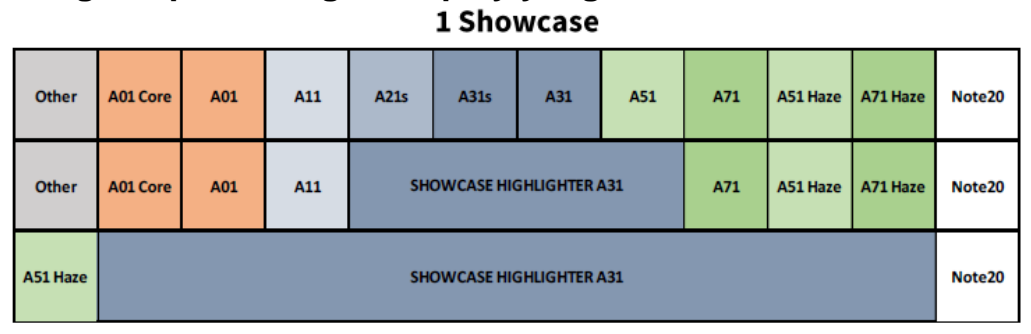

Gambar 3. planogram display 1 etalase

Pada planogram 1 etalase (gambar 3) ini terlihat dari jenis peasangan stock atau dummy box yaitu sebelah kiri tipe yang paling kecil lalu ke kanan menjadi tipe yang lebih besar dan di bagian tengah etalase di beri showcase highlighter A31.

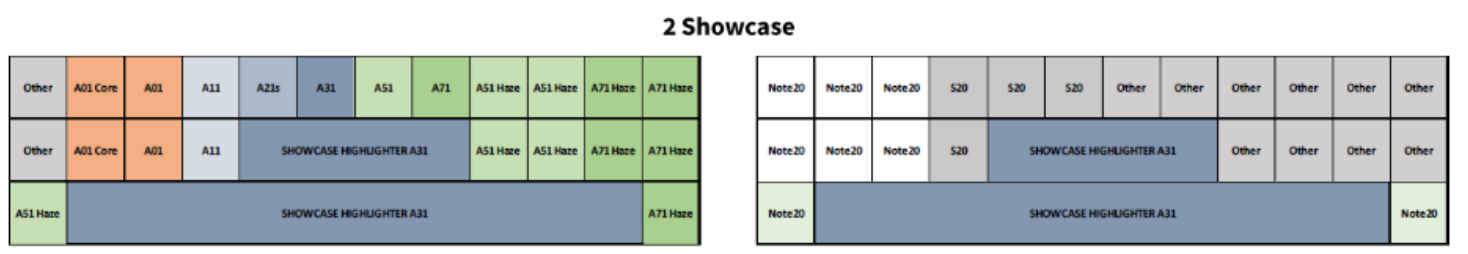

Gambar 4. planogram 2 etalase

Untuk 2 etalase (gambar 4) hampir sama dengan 1 etalase namun disini dibedakan antara isi di etalase sebelah kiri dan kanan. Yaitu untuk etalase yang kiri penataan dari seri terkecil menuju yang lebih besar. Dan untuk etalase yang bagian kanan dari type yang terbesar menuju seri yang terkecil.
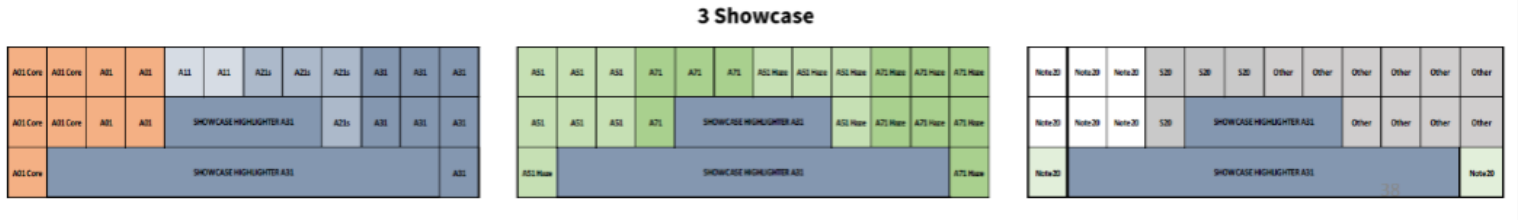

Gambar 5 planogram 3 etalase

Untuk 3 etalase (gambar 5) hampir sama dengan 2 etalase namun disini dibedakan antara isi di etalase sebelah kiri, tengah dan kanan. Yaitu untuk etalase yang kiri penataan dari seri terkecil JURNAL ILMIAH KOMPUTER GRAFIS Vol. 13, No. 2, December 2020 : 42-55 
dari A01 core menuju ke tipw A31. Dan untuk etalase bagian tengah hanya diisi 2 Tiple middle dari Samsung yaitu A51 dan A71. Dan pada bagian etalase ke 3 atau sebelah kanan sendiri berisikan type premium dari produk Samsung. Sehingga disini terlihat pembagian segmen untuk masing-masing display etalase yang ada untuk memudahkan pengunjung fokus terhadap type yang akan di beli.

\subsubsection{Pembuatan media etalase dan dummy Box}

Tahap selanjutnya setelah mengetahui basic planogram, progam SketchUp digunakan untuk membuat elase (gambar 6) yang sama dengan yang ada di tokodengan panjang tinggi dan lebar sesuai dengan keadaan aslinya.
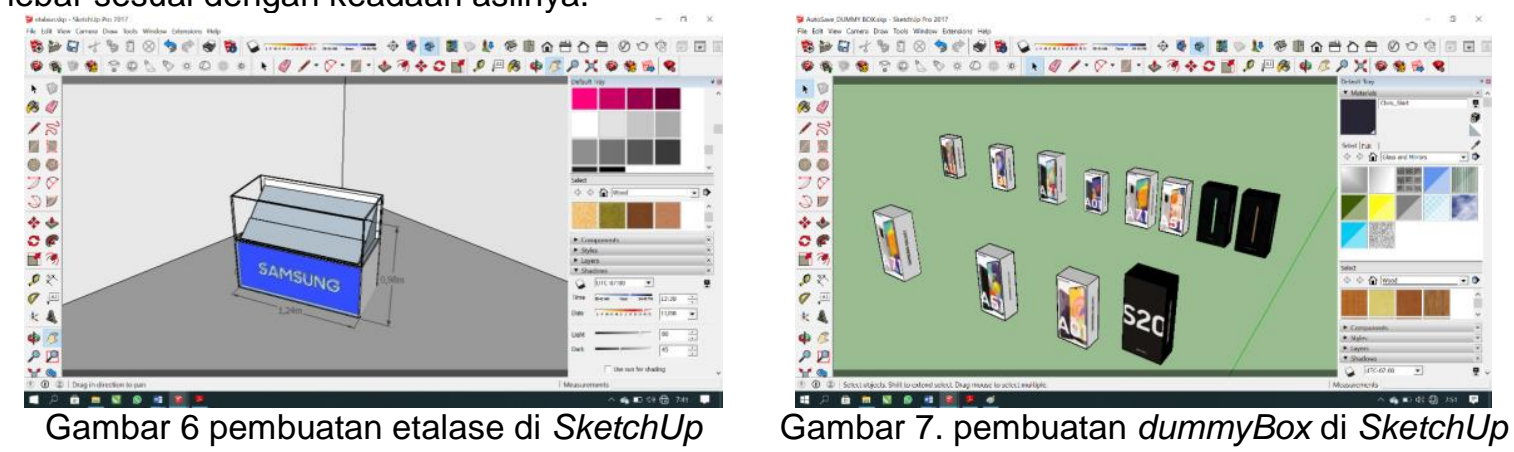

Tahapan selanjutnya setelah etalase sudah siap penulis melakukan editing setiap masing-masing type box produk Samsung dari seri terkecil yaitu A01 Core, A01, A11, A21s, A31, A51, A71, Note 20 , S20. Setelah proses editing gambar box nya kita membuat 3D di sketchup berupa box kosong sesuai dengan ukuran real box yang ada di toko. Untuk hasilnya bisa dilihat di gambar 7 .

Langkah selanjutnya setelah etalase dan dummy box 3D sudah terbuat adalah membuat rangkaian etalase sesuai dengan planogram yang ada menurut standart Samsung yang ada di toko.

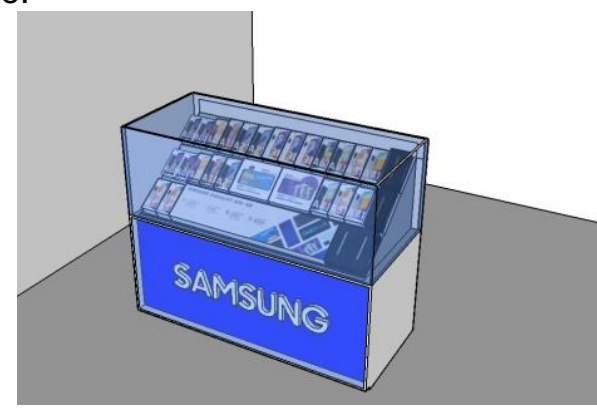

Gambar 8. Visual 3D planogram 1 etalase

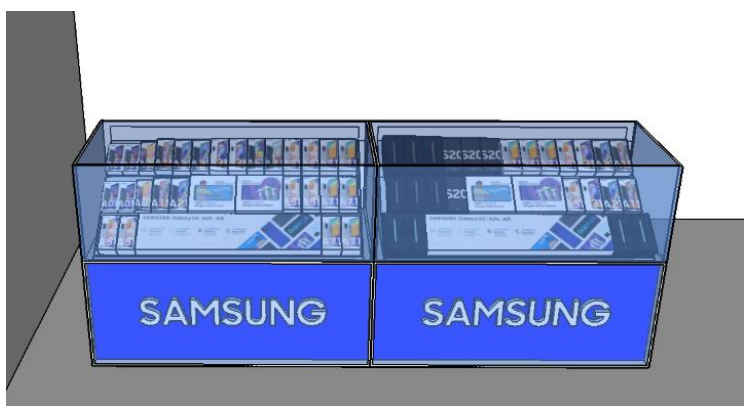

Gambar 9. visual 3D 2 etalase

Pada saat visual 3D di sketcup sudah terlihat sesuai dengan yang ada di planogram 1 etalase (gambar 8). Dalam bentuk seperti iki akan lebih mempermudah dan menarik promotor untuk melihat acuan pemasangan dummy box yang ada di toko masing-masing.

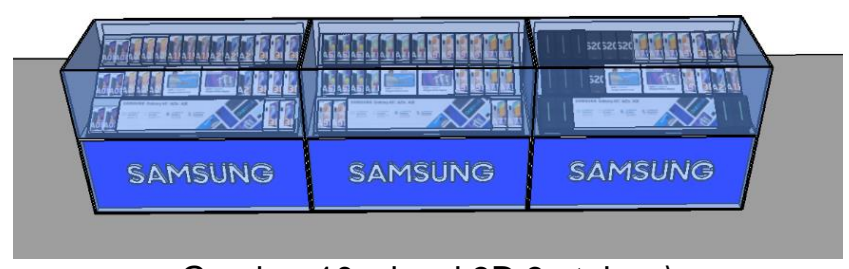

Gambar 10. visual 3D 3 etalasel 
Pada Tahap ini sudah menjadi awalan untuk pembuatan 3D visual planogram. Yang dibedakan menjadi 3 etalase (gambar 9 dan 10). Namun pengunaannya bisa menyesuaikan dengan jumlah etalase yang ada di masing-masing toko. Karena tidak semua memiliki standart yang sama. Dan untuk tahapan selanjutnya adalah pembuatan material promosi pendukung yang ada.

\subsubsection{Pembuatan POSM pendukung yang ada di dalam toko}

Untuk POSM pendukung ini yang dimaksud adalah tripod, poster A4, acrylic brosur dll. Pembuatan desain menggunakan sketchup juga dengan dipatukan dengan editing di Corel Draw dan Adobe Pothoshop untuk mengedit gambar yang terdapat untuk teksture di masing masing item POSM.
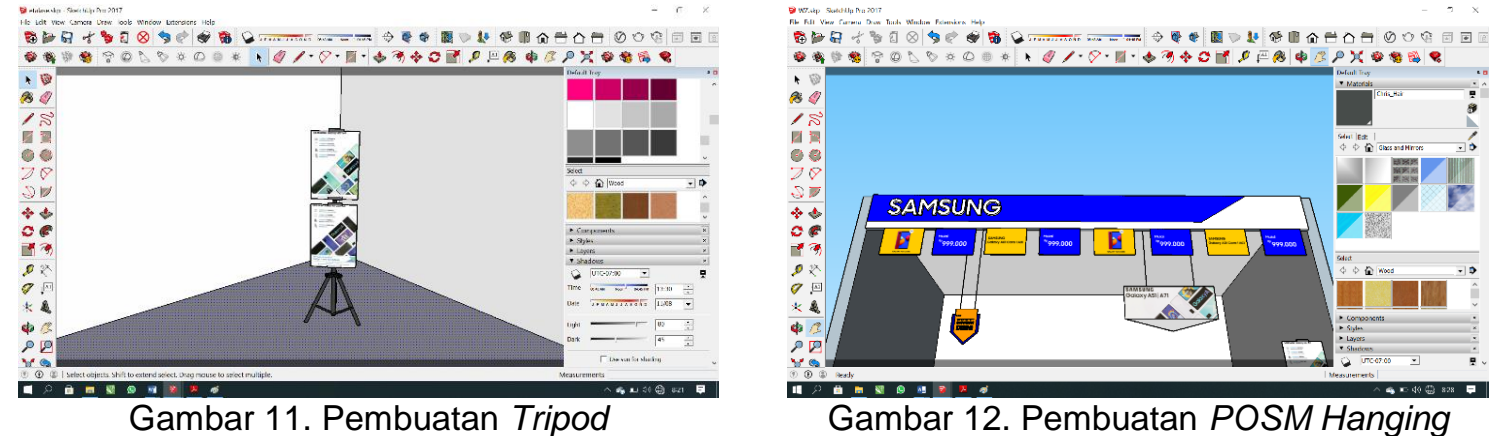

Pembuatan tripod ini (gambar 11) disesuailkan dengan bentuk asli yang ada di toko dengan ukuran yang sama. Tripod ini bisa untuk memasang POSM berupa foamboard 2 muka pada bagian atas dan bawah. POSM ini bertujuan untuk memberi informasi pengunjung yang akan masuk ke dalam toko.

Untuk langkah selanjutnya Pembuatan material promo yang ada dibagian atap toko atau langitlangit di toko. POSM ini terdiri dari flag chain yang dipasang di depan toko dibawah shopsign sebuah toko berbentuk bendera dan berbahan kertas agak tebal, selain itu juga ada hanging banner dengan berbagai ukuran yang dipasang dan dikaitkan dengan atap menggunakan perekat dengan tali. Masing-masing POSM hanging (gambar 12) seperti ini berfungsi untuk memberikan tanda atau media supaya konsumen mengetahui bahwa ada produk Samsung yang dijual di toko tersebut.

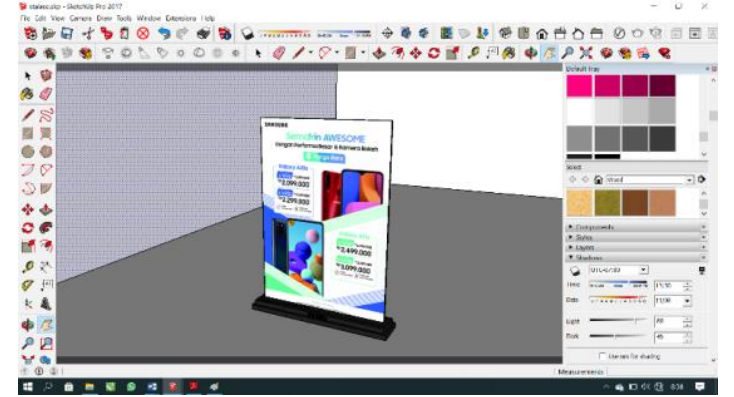

Gambar 13. Pembuatan Acrylic Poster A4

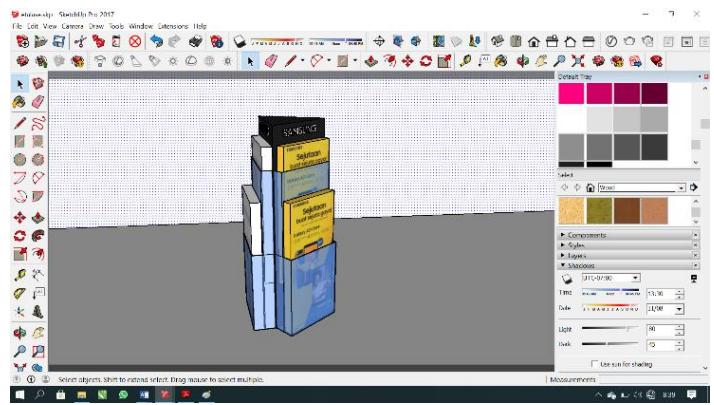

Gambar 14. Pembuatan Acrylic Brosur

POSM acrylic poster A4 (gambar 13) dipasang di atas etalase, ukuran material promo ini dalah sesuai dengan kertas A4 dan bisa dipasang 2 lembar bolak balik. Tujuan dari POSM ini adalah untuk menempel promo yang sedang berjalan sehingga saat konsumen ada di depan etalase dapat melihat promo apasaja yang sedang berlangsung saat ini.

Posm acrilic brosur atau leaflet (gambar 14) dipasang di atas etalase . ini adalah tempat untuk memasang leaflet atau brosur produk yang sudah disediakan oleh perusahaan. Hal ini bertujuan untuk konsumen lebih mengetahui tentang produk yang di release oleh Samsung dan konsumen bisa mengambil brosur yang sudah dicetak. 


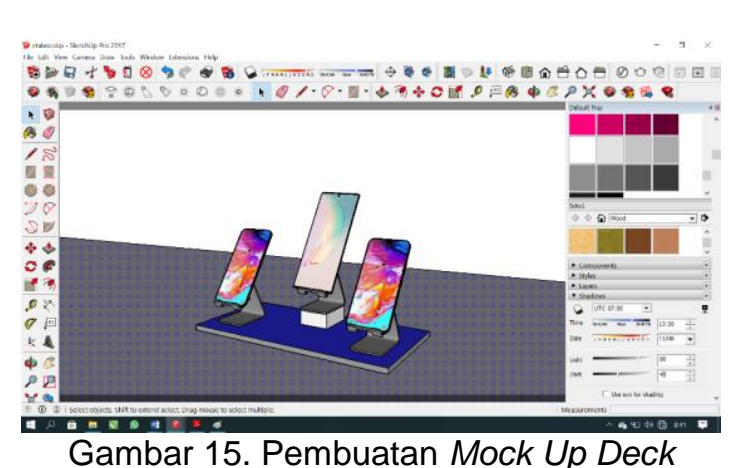

Gambar 15. Pembuatan Mock Up Deck

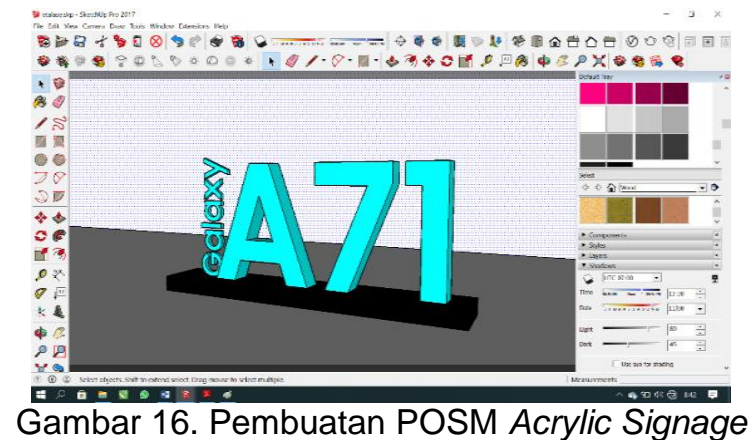

Gambar 16. Pembuatan POSM Acrylic Signage

Mock Up Deck (gambar 15) adalah material promosi untuk meletakan dummy atau contoh barang yang sama dengan bentuk smartphone yang dilaunching. Material promo ini sangat efektif untuk menarik konsumen yang akan membeli sebuah smartphone, peletakan di atas etalase sehingga konsumen mudah memegang dummy atau contoh produknya.

Acrylic Signage (gambar 16) adalah POSM berbentuk acrylic dengan tulisan produk, peletakan material promosi ini di atas etalase yang bertujuan menunjukan konsumen bahwa produk tersebut di stock atau dijual oleh pihak toko.

\subsubsection{Peletakan material promosi / POSM}

Pada tahap selanjutnya setelah semua proses pembuatan 3D POSM adalah menggabungkan manjadi satu kesatuan sehingga terlihat gambaran yang mudah dipahami oleh promotor untuk pemasangan semua material promosi yang ada di toko. Berikut gambaran tentang peletakan di salah satu contoh toko (gambar 17).

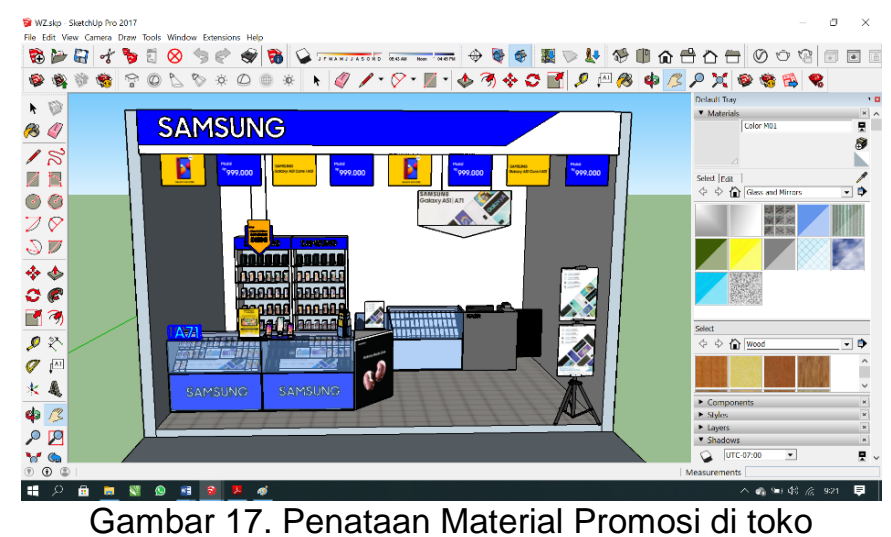

Setelah mendapatkan sebuah desain toko yang ada selanjutnya kita melakukan take animation perbagian material promosi yang bertujuan untuk mengambil footage ditahap editing video. Dan melakukan render perbagian yang digunakan untuk bahan modul Acuan planogram visual 3D yang akan dibuat. Diharapkan dengan pembuatan video visual 3D dan modul Acuan Planogram ini dapat memudahkan promotor untuk melakukan pemasangan dan pemahaman akan nama - nama material promosi yang ada di toko.

Untuk video Visual 3D akan menjelaskan mengenai nama material promosi yang sudah dirancang di sketchup dan peletakannya di dalam toko. Dan untuk durasinya kurang lebih 5 menit untuk mempercepat proses pemahaman promotor dan langsung bisa untuk ekseskusi pemasangan. Dan untuk file modul acuan akan lebih lengkap untuk masing - masing tipe toko yang ada di retail Samsung saat ini. 


\subsubsection{Publikasi video dan Modul Visual 3D planogram}

Setelah pembuatan video dan modul visual 3D planogram retail Samsung, selanjutnya adalah tahap pempublikasian, yang pertama adalah di publikasi ke semua promotor yang ada di toko, dan yang kedua akan bertahap di uplod di youtube dan google drive supaya dilihat secara langsung apabila ada yang membutuhkan video dan modul tersebut. yang selanjutnya menyerahkan hasil soft copy dan menunjukan proses semua dari awal kepada manager PT.Accentuates Jateng yang selanjutnya akan di jadikan arsip di perusahaan dan juga digunakan sebagai media pelengkap untuk acuan pemaangan material promosi yang sudah ada, adapun tujuan dari publikasi ini adalah untuk memberikan ketertarikan dan kepercayaan promotor sehingga semua POSM yang sudah dibuat oleh perusahaan tersampaikan ke konsumen dengan baik. Dan diharapkan menjadi penambah sellout di masing masing toko karena penataan display yang menarik akan lebih membuat konsumen jelas akan promo yang sedang berjalan dan untuk memutuskan pembelian di toko tersebut.

\subsubsection{Validasi Produk Akhir}

Hasil Produk akhir divalidasi dari pihak internal Manager Area Jateng PT.Accentuates :

a. Desain yang menarik memperoleh nilai $A B$ dengan nilai rata-rata 81-85.

b. Istilah mudah dipahami memperoleh nilai $A B$ dengan nilai rata-rata 81-85.

c. Isi video visual $3 D$ planogram sesuai dengan konsep yang dibuat memperoleh nilai $\mathrm{A}$ dengan rata rata 86-100.

d. Mampu diputar di smartphone mendapatkan nilai A dengan nilai rata-rata 86-100.

e. Dapat diputar di media player atau komputer memperoleh nilai A dengan nilai rata-rata 86100.

f. Informasi lengkap dan jelas memperoleh nilai $A B$ dengan nilai rata-rata 81-85

g. Teks dapat dibaca denga jelas memperoleh nilai $A B$ dengan skor rata-rata 81-85

$\mathrm{h}$. Dengan pertanyaan gambar jelas sesuai dengan POSM yang ada di toko mendapat nilai $A B$ dengan rata-rata 81-85.

Dari pihak Ahli pakar visual 3D dari perguruan tinggi memberikan nilai sebagai berikut :

a. Desain yang menarik memperoleh nilai $A B$ dengan nilai rata-rata 81-85.

b. Istilah mudah dipahami memperoleh nilai $A B$ dengan nilai rata-rata 81-85.

c. Isi video visual $3 D$ planogram sesuai dengan konsep yang dibuat memperoleh nilai $A$ dengan rata rata 86-100.

d. Mampu diputar di smarphone mendapatkan nilai AB dengan nilai rata-rata 81-85.

e. Dapat diputar di media player atau komputer memperoleh nilai $A B$ dengan nilai rata-rata 8185.

f. Informasi lengkap dan jelas memperoleh nilai B dengan nilai rata-rata 73-80.

g. Teks dapat dibaca denga jelas memperoleh nilai B dengan skor rata-rata 73-80

h. Dengan pertanyaan gambar jelas sesuai dengan POSM yang ada di toko mendapat nilai $A B$ dengan rata-rata 81-85.

\section{Kesimpulan}

Perancangan media untuk membantu pemasangan material promosi yang ada di retail Samsung berupa visual $3 D$ planogramyang dapat memvisualisasikan dengan nyata dengan adanya teks, gambar, dan video, media ini dapat dilihat dari hasil uji validasi yang telah dilakukan oleh pakar ahli dan validasi user bahwa untuk aspek visualisasi video dan modul planogram $3 \mathrm{D}$ yang telah dikembangkan oleh penulis masuk kedalam kategori rata-rata nilai $A B$ dengan skor 81-85 .Selain itu, melalui uji lapangan yang diwakili oleh 30 responden dapat disimpulkan bahwa untuk hasil planogram 3D, media yang telah dikembangkan oleh peneliti masuk kedalam kategori sangat baik dengan presentase $78 \%$ untuk segmen promotor yang lebih dari 1 tahun dan $77 \%$ untuk segmen promotor baru yang kurang dari 1 tahun bekerja di retail Samsung.

Secara keseluruhan dapat disimpulkan bahwa peneliti telah berhasil mengimplementasikan media visual 3D planogram yang dapat menyampaikan informasi dengan visualisasi penataan material promosi dan stock dislay yang ada di retail Samsung. Dan proses

JURNAL ILMIAH KOMPUTER GRAFIS Vol. 13, No. 2, December 2020 : 42-55


penataan display dapat dilakukan lebih cepat dan tepat dikarenakan pemahaman akan planogram meningkat. Sehingga promosi yang sedang berjalan dapat diterima oleh konsumen yang masuk ke toko retail Samsung yang diharapkan dapat meningkatkan jumlah penjualan brand Samsung khususnya di area Salatiga dan Ambarawa.

\section{Daftar Pustaka}

1. Wijanarko, K. (2014). Pengaruh Nilai Pelanggan Terhadap Kepuasan Serta Dampaknya Terhadap Loyalitas Menggunakan Smartphone Samsung Galaxy Series Di Kota Palu. Katalogis, 2(7), 34-46.

2. Haryanto, R., Octavia, T., \& Sugianto, R. (2018). Pengaruh Peletakan Display Produk Berdasarkan Prinsip 5R dan Planogram terhadap Peningkatan Penjualan : Studi Kasus pada Ritel X di Lamongan. Jurnal Titra, 6(2), 385-392.

3. Danny Setiawan, (2008) Pengaruh store environment terhadap impulse buying behavior untuk produk makanan ringan di Hypermart Royal Plaza. Bachelor thesis, Petra Christian University.

4. Melisa Cancerina Sanyogo, (2013) Efektifitas Point Of purchase dalam meningkatkan impulse buying pada peritel di Surabaya,1-5.

5. Utami, Christina W. (2010). Manajemen Ritel. Jakarta: Salemba Empat.

6. IM Retail Planing \& Budgeting. (2020). RIS Samsung Retail Update 2020. Jakarta

7. Field Force management. (2017). Smartbook Samsung Experience Consultant. Jakarta.140 hal.

8. Faiztyan, I. F., Isnanto, R. R., \& Widianto, E. D. (2015). Perancangan dan Pembuatan Aplikasi Visualisasi 3D Interaktif Masjid Agung Jawa Tengah Menggunakan Unity3D. Jurnal Teknologi Dan Sistem Komputer, 3(2), 207. https://doi.org/10.14710/jtsiskom.3.2.2015.207-212

9. Lewison, D. M., dan DeLozier, M. W., 1989, Retailing, Third Edition, Columbus, Ohio: Merrill. Publishing Company.

10. Schor, J. (2005). Point of Purchase. Contemporary Sociology: A Journal of Reviews, 34(1), 43-44. https://doi.org/10.1177/009430610503400127 